\title{
全身麻酔下での直腸癌術中にアナフィラキシーを起こした 高齢者のラテックスアレルギーの一例
}

田村 利尚, 日暮 愛一郎, 永田 直幹, 平田 敬治, 中山 善文, 岡本 好司, 山口 幸二

産業医科大学 医学部 第一外科学講座

要 旨：直腸癌に対する前方切除術開始直後に, ラテックスアレルギーによるアナフィ ラキシーショックを来した症例を経験した，症例は72 歳, 女性．直腸癌に対し 直腸高位前方切除術を施行した。執刀開始から約 15 分後に突然, 気道内圧の上 昇, 血圧·動脈酸素飽和度 $\left(\mathrm{SpO}_{2}\right)$ の低下を認め, 同時に全身の紅潮, 喘鳴, 心電図 異常が見られた．ラテックスによるアナフィラキシーショックを疑い, 手術を 中断, アナフィラキシーショックに詨する治療により救命し得た. 術後, ラテ ックスアレルギーに対する検査を施行したところ, 血中ラテックス特異免疫グ ロブリン $\mathrm{E}(\mathrm{IgE})$ 抗体值が高值を示し, ラテックスによるアナフィラキシーショ ックと診断した．ラテックスフリーの環境で再手術を行い無事に終了した.

キーワード：ラテックスアレルギー,アナフィラキシーショック, 全身麻酔.

（2008 年10月10日 受付, 2009 年1月22日 受理）

はじめに

ラテックスアレルギー(LA：Latex Allergy) は, 天然ゴムのタンパク質を抗原とするIgE抗 体介在性即時型アレルギー反応であり, 1990 年代以降様々な分野から数多くの報告がな された，その結果, LAが認知されるとともに ラテックス抗原溶出の低減化やラテックス フリー化への努力がなされ, 現在ではLAの報 告例は減少傾向にある。しかし, 尚, 緊急手 術時の問診不足によってLAに伴うアナフィ ラキシーショックを起こした症例や注腸造 影時など麻酔科の術前問診を介さない症例 の報告が散見される。今回は，医療従事者の
LAに対する認識を高める意味も含め, 当科で 経験した全身麻酔下に直腸癌に対する前方 切除術開始直後に生じたLAの一例を報告す る.

症 例

患 者：72 歳, 女性.

主 訴: 粘血便, 便通異常, 便狭小化.

既往歴：52 歳時, 胃癌に対し幽門側胃切除術 を受ける。全身麻酔下手術であったが周術 期合併症は認めず。

アレルギー歴：20 歳時歯科治療の際, ペニシ リンにて顔面紅潮, 蕁麻疹の出現あり.60歳 時, 下顎部切創に対し局所麻酔下に縫合処置 
を受けた際, 急激な血圧低下あり。食物アレ ルギー,花粉症や鼻炎の既往はなし。

家族歴：特記事項なし。

現病歴：平成 15 年 4 月より粘血便を自覚する も痔からの出血と思い放置していた。同年9 月から便通異常, 便の狭小化を認め, 近医を受 診。精査にて直腸癌と診断され, 手術加療目 的に同年11月当院当科入院となった.

入院時血液検査成績：特記事項なし。

胸·腹部X線写真：特記事項なし。

大腸内視鏡検查 (Fig. 1): 肚門縁加ら約 $15 \mathrm{~cm}$ の直腸 $\mathrm{S}$ 状部に, 全周性の隆起性病変を認め た. 生検の結果は中分化型腺癌の診断であっ た。

注腸検查 (Fig. 2)：直腸 $\mathrm{S}$ 状部に狭窄病変を認 めた。

入院後経過:上記アレルギー歴があったため, 術前, 抗菌薬(セフメタゾールナトリウム). 局所麻酔薬(塩酸りドカイン/塩酸メピバカイ ン/塩酸ロピバカイン)の皮内反応を施行した

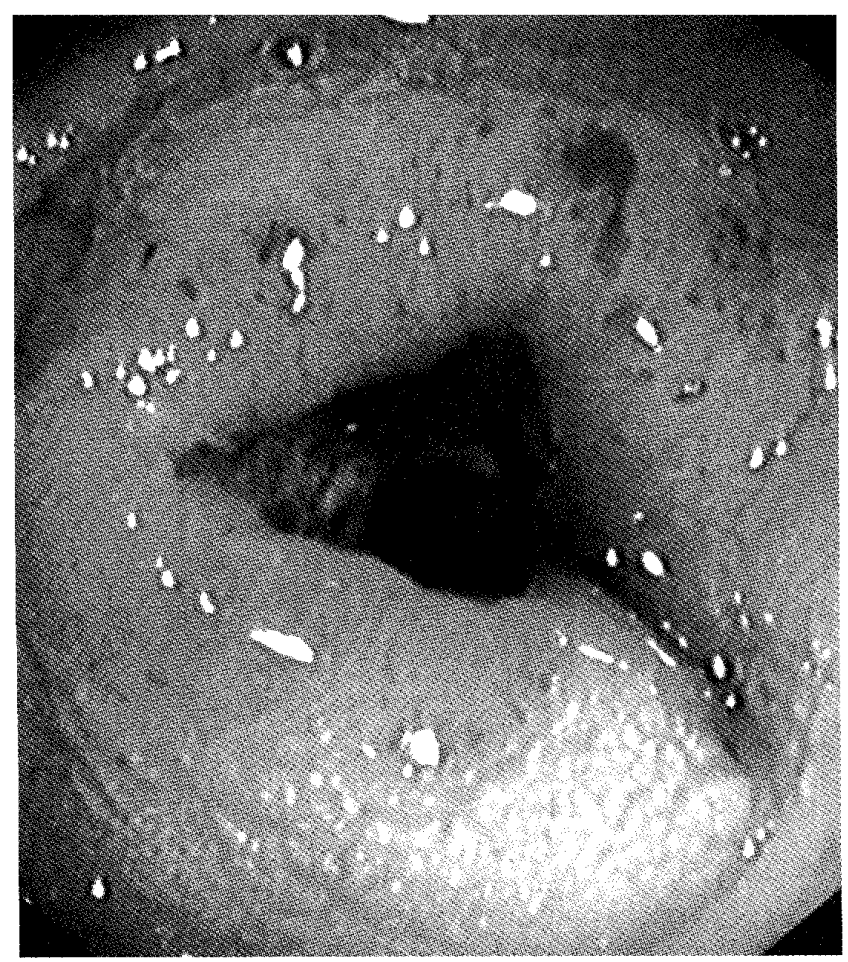

Fig. 1. Colonoscopy showed a protruding tumor in the sigmoid portion of the rectum at a site of $15 \mathrm{~cm}$ from the anal verge.
が，いずれも㓌性であった，直腸癌の術前診 断に対し, 平成15 年11月に直腸高位前方切除 術を施行した。

術中経過(Fig. 3-5): 麻酔経過としては, 手 術室入室後第 12 胸椎・第 1 腰椎間より硬膜外 カテーテルを留置, テストとして $2 \%$ 塩酸メピ バカインを $2 \mathrm{ml}$ 注入した。この際ラテックス 製のゴム手袋を使用したが特に問題なかっ た。 導入はプロポフォール $100 \mathrm{mg}$ で行い, 臭 化ベクロニゥム9 mgで筋弛緩を得て気管内 扫管を行った。またラテックス製の尿道力 テーテルを留置した，麻酔は酸素 $2 \ell / \mathrm{min}$, 笑 気 $2 \mathrm{l} / \mathrm{min}$, セボフルラン $0.6 \%$ の吸入麻酔にて 維持した。 入室から執刀までの間, バイタル サインは安定して経過した。術者 4 人全員ラ テックス製のゴム手袋を使用して手術を開 始した。手術開始と同時に抗菌薬の点滴投 与を開始した。執刀から約 15 分後の癒着剥 離時に突然, 気道内圧の上昇, 血圧の低下を認 めた。同時に全身の紅潮, 喘鳴, 動脈酸素飽和

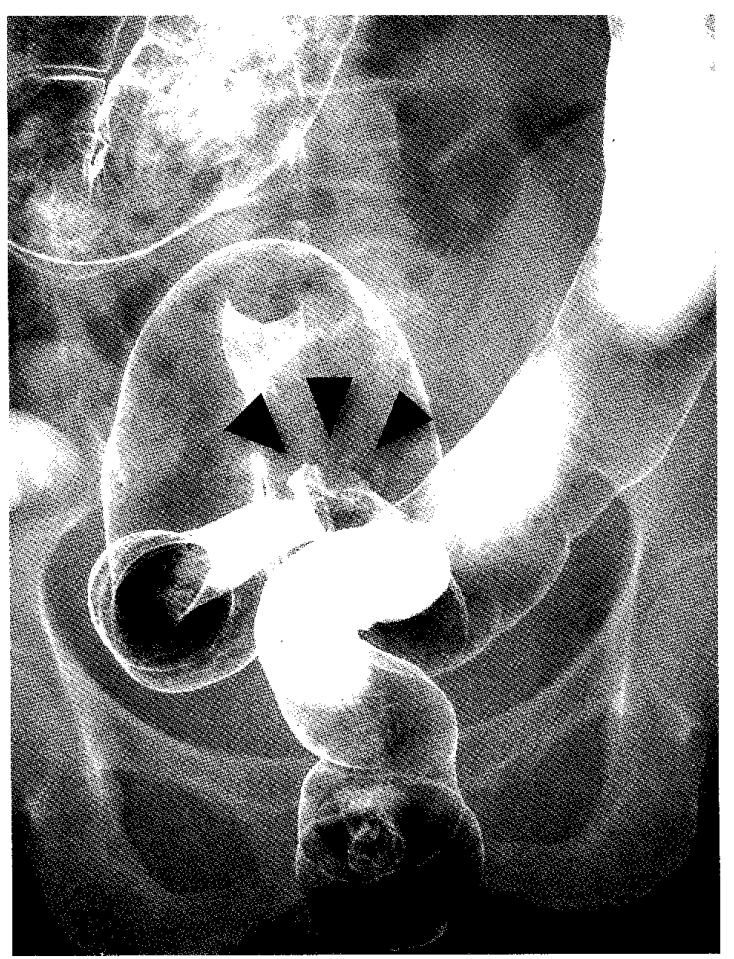

Fig. 2. Barium enema showed stenosis at the sigmoid portion of the rectum. 
度 $\left(\mathrm{SpO}_{2}\right)$ の軽度低下,心電図異常を伴ったた め, 麻酔科医よりラテックスによるアナフィ ラキシーショックを指摘された。手術を一時 中断し,アナフィラキシーショックに対する 治療を開始した，急激な血圧低下に対し塩酸 フェニレフリン静注するも著変なく, エピネ フリンの皮下注を施行．徐々に血圧上昇を認 めたが不安定なため，塩酸ドパミンならびに ノルエピネフリンの持続静注を開始した，依 然血圧低下傾向にあったため, エピネフリン 静注施行したところ，血圧は上昇した。エピ ネフリン静注にて徐々に血行動態は安定した が手術続行は不可能と判断し, ラテックスフ リーの手袋に交換後, 閉腹とした。全身の紅 潮が持続していたため，挿管状態のまま集中 治療室へ移送, 紅潮が軽減するまで人工呼吸 管理を行った。麻酔時間, 手術時間はそれぞ れ2 時間55 分, 1 時間18 分. 術中出血量は少 量で, 輸液総量は約 $2000 \mathrm{ml}$, 術中尿量は約 400 mlであった。
$8: 30$ 手術室入室

Blood pressure: $162 / 80 \mathrm{mmHg}$ Pulse rate: $77 / \mathrm{min}$

$\mathrm{SpO}_{2}: 94 \%$

8:40 硬膜外カテーテル留置 Test:2\%塩酸メピバカイン $2 \mathrm{ml}$ Blood pressure: $158 / 78 \mathrm{mmHg}$ Pulse rate: $77 / \mathrm{min}$

$\mathrm{SpO}_{2}: 96 \%$

$8: 55$ 全身麻酔導入 プロポフォール $100 \mathrm{mg}$ 臭化ベクロニウム $9 \mathrm{mg}$ 気管内挿管

維持麻酔 (吸入麻酔)

$\mathrm{O}_{2} 2 \ell / \mathrm{min}, \mathrm{N}_{2} \mathrm{O} 3 \ell / \mathrm{min}$, セボフルラン $0.6 \%$

9:17 手術開始

Fig. 3. Anesthetic course.

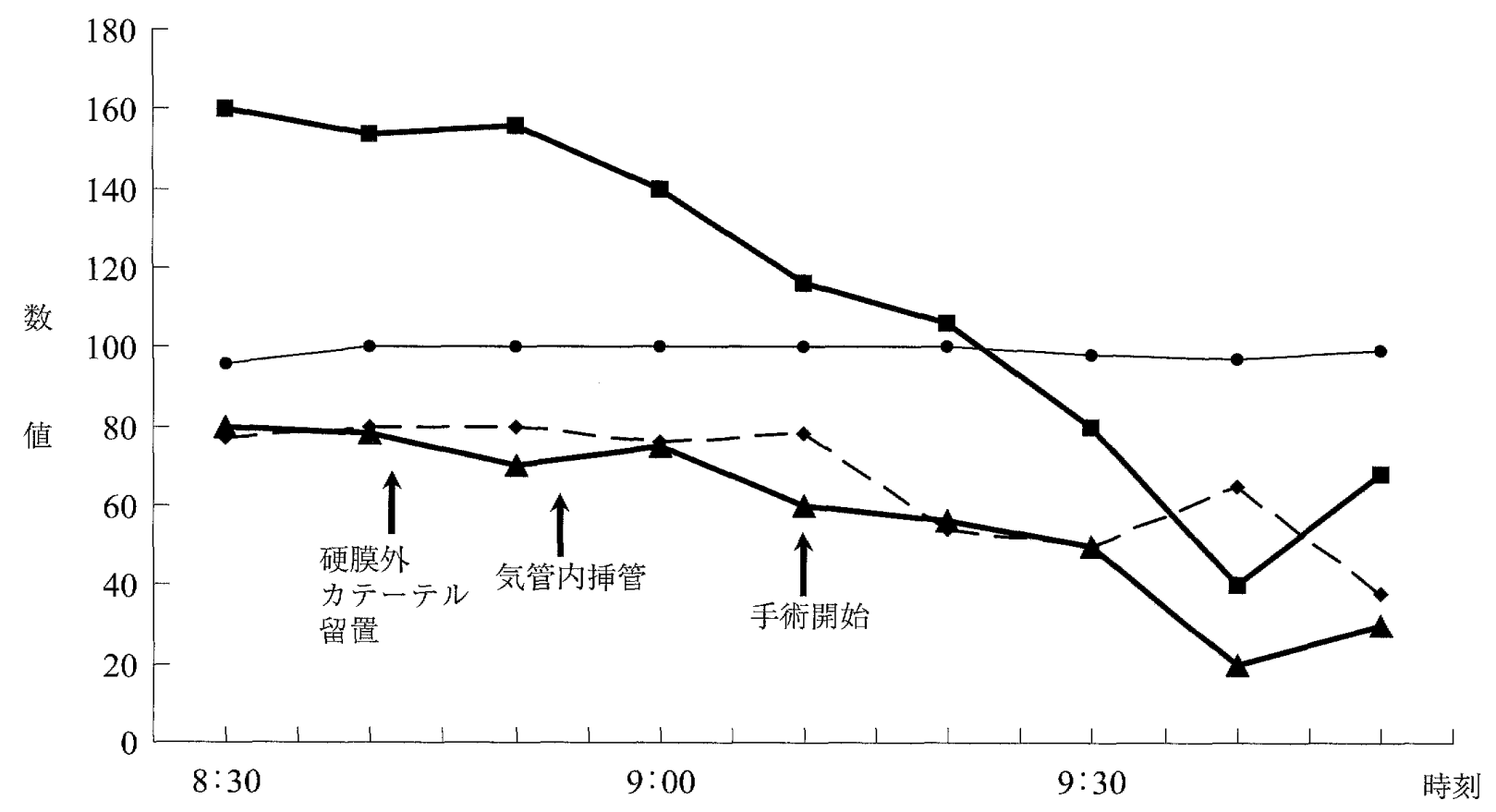

Fig. 4. The vital signs from the anesthesia to the anaphylaxis.

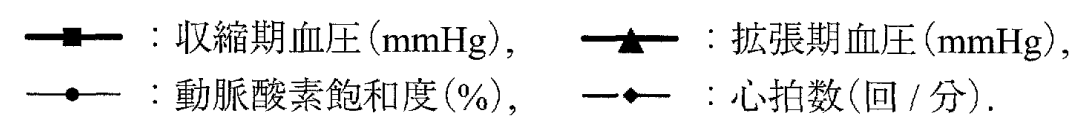




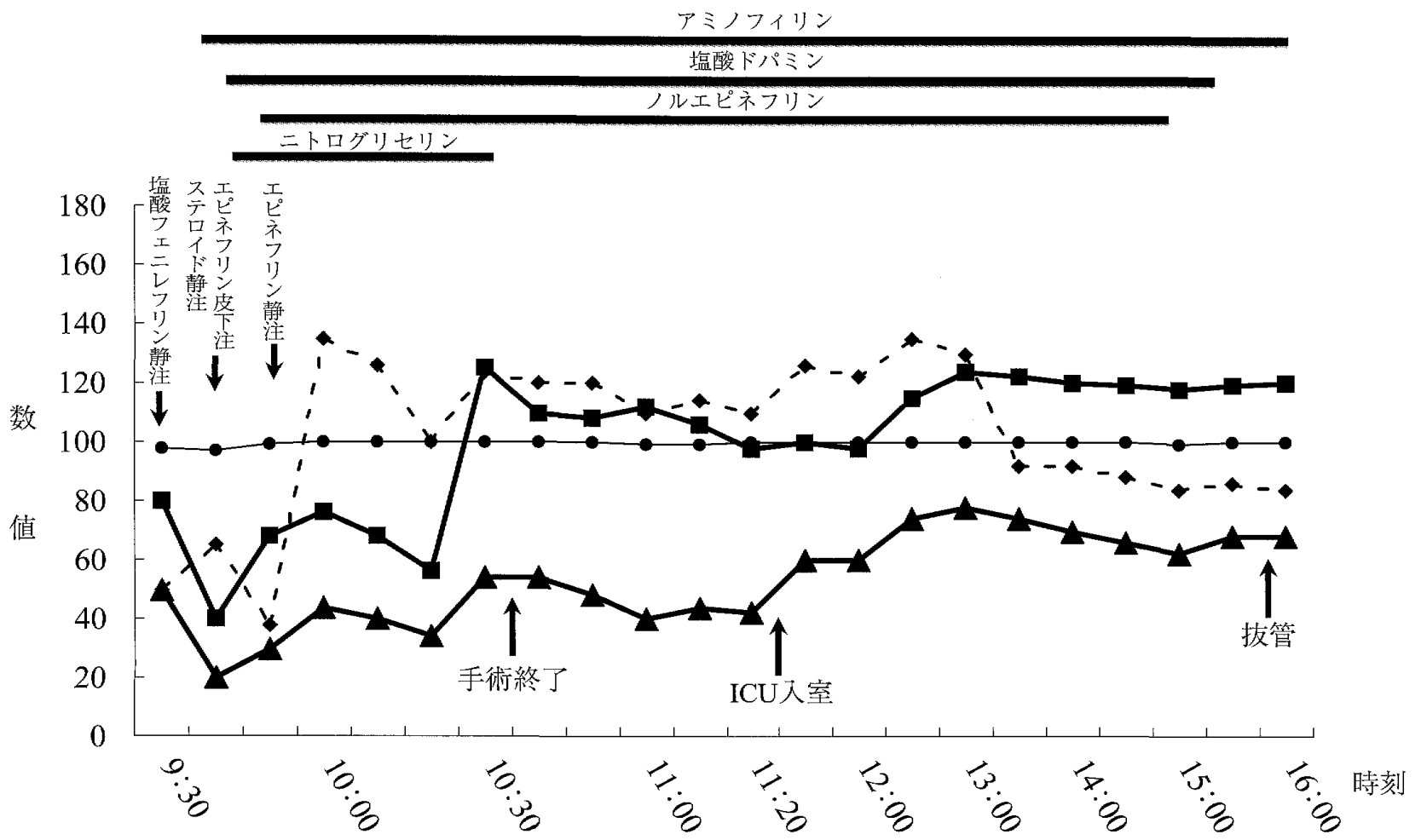

Fig. 5. The vital signs from the anaphylactic shock to the post-operation course.

$\longrightarrow$ 一：収縮期血圧 $(\mathrm{mmHg}), \longrightarrow$ ：拡張期血圧 $(\mathrm{mmHg})$, $\longrightarrow$ - 動脈酸素飽和度 $(\%),-\rightarrow-$ : 心拍数 (回/分).

術後経過 (Fig. 5)：集中治療室入室後, 血圧の 低下などは認めず, バイタルサインは安定し て経過した．血液一般検査, 動脈血ガス分析, 胸部X線や心電図上，異常所見は認めなかっ た.アミノフィリン持続静注にて経過観察 とし, 全身の紅潮も次第に消失したため, 手術 開始から約 7 時間後に抜管, 翌日集中治療室 を退室となった。術後に施行した放射線アレ ルギー吸着検查法 (RAST: radioallergosorbent test）による血中ラテックス特異IgE RASTは Class 2 と陽性を示した，再手術は，当院手術 室にあるラテックスアレルギー対応デイスポ 物品を使用するなど, ラテックスフリーの環 境下で行った。術中アレルギー症状は認め ず,手術を終了した。
考察

LAは1979 年にNutterによって初めて報告 された [1]．その後欧米にて感染症子防の観 点からラテックス製手袋の使用頻度の増加に 伴い, 1990 年代からLAによるアナフィラキ シーの報告が相次ぐようになった，日本でも 1993 年以降急速に症例報告が増加, 2000 年に 入ってからは医療従事者間での蔓延が問題と なり，有病率の調査・報告がなされ[2]，医療従 事者への啓発が発せられている。現在, 大学 病院などの手術室・救急部などではラテック ススリーの環境が整えられつつある。一方 で, ラテックスは優れた防御性, 機能性, 触感, またコストパフォーマンスの良さがあり，ラ テックス抗原溶出の低減化はなされている 
が,ラテックス蛋白を含む医療用品は現在も 使用されている。それゆえ, 術前問診に扔け るLAのチェックのルーチン化や患者により ラテックスフリー環境の整備が行われ $[3,4]$, 現在ではLAの報告例は減少傾向にある。

自験例は, 全身麻酔下に手術開始後約 15 分 後にショックを発症したが,一般的に術中の アナフィラキシーショックの原因としては, 筋弛緩薬が58.2\%でもっとも多く, ラテック スは $16.7 \%$ で2 番目の頻度であると報告され ている $[5]$. また, 開腹直後に生じうるショッ クとしては,アナフィラキシー反応または腸 間膜变引症候群 $[6,7]$ が考えられるが,筋驰緩 薬初回投与後約 1 時間経過していること, 開 腹值後に発症していることより, 抗原曝露経 路としては術者の手袋が腹部内臓に接触し， 水溶性蛋白が血中に移行したと考えられた。

LAの診断としては, 詳細な問診が重要であ り，疑った場合に血清学的試験や皮膚試験を 行う。問診上重要なことは,LAを起こしやす いハイリスクグループ[8]に含まれるかどう かをチエックすることである。自験例では， 術前の問診上, LAのハイリスクグループには 当てはまらなかった，また全身麻酔下での開 腹手術の既往があり,その際周術期合併症を 認めなかったこともあり，術前にLAに対する 詳細な問診は行われなかった。尚, 抗菌薬.
局所麻酔薬に対するアレルギー歴を有したた め，術前に皮内テストを行ったが陰性であっ た。術後LAに関する詳細な問診を行ったが, 普段の日常生活において接触寻麻疹などの既 往はなかった，高歯であったため，親族にも 病歴の聴取を行ったが明確な症状は同定でき なかった.しかし, 60 歳時の下顎切創の処置 の際の血压低下は, 局所麻酔薬ではなくLAに 伴うアナフィラキシーショックであった可能 性が考えられ，術前にLAの可能性を疑うべき たっっと思われる，当時，当科に执いてLAに 対する認識が薄かったことは反省すべき点で あり，現在では当科に招いても術前にLAに関 する詳細な問診を行うようにしている。

上述したように, 医療従事者のLAに対する 認識の向上, 医療環境の改善に伴い頻度は減 少しているが, 最近でも緊急手術時の問診不 足によってLAに伴うアナフィラキシーショ ックを起こした症例が散見され[9]，また術前 問診を介さない症例についての対応などの問 題があるのも事実である $[10,11]$ 。今回, 医療 従事者のLAに対する認識を再度高める意味 も含め, 全身麻酔下での術中にアナフィラキ シーを起こした高齢者のラテックスアレルギ 一の一例を報告した。

\section{引用 文 献}

1. Nutter AF (1979) : Contact urticaria to rubber. Br J Dermatol 101:597-598

2. 加野尚生, 矢上晶子, 鈴木加余子, 他 (2004）：一大学病院の全医療従事者を対象としたラテッ クスアレルギーについての意識·実態調查.アレルギー 53:659-668

3. 近藤陽一, 阿部世紀, 田村高子, 他 (2000) : ラテックスセーフな手術環境作り。臨床麻酔 $24: 849-853$

4. 松永佳世子 (2000)：ラテックスアレルギー。皮膚病診療 $22 ： 1123-1128$

5. Mertes PM, Laxenaire MC, Alla F et al (2001): Anaphylactic and anaphylactoid reactions occurring during anesthesia in France in 1999-2000. Anesthessiology 99:536-545

6. 須山豪通, 河本昌志, 山野上敬夫, 他 (1995): 術中の腸管率引により不整脈とST低下を生じた 1例。麻酔と蘇生 $31: 265-266$ 
7. 城山和久, 森脇克行, 弓削猛文, 他 (1996)：腹腔内洗浄後に重篤な血圧低下と全身紅潮が生じ た1 例。臨床麻酔 $20: 435-436$

8. Beezhold DH, Sussman GL, Liss GM et al (1996): Latex allergy can induce clinical reactions to specific foods. Clin Exp Allergy $26: 416-422$

9. 小澤悟, 堀田司, 岩橋誠, 他（2007）：緊急開腹手術中にアナフィラキシーショックを扢こした ラテックスアレルギーの1 例. 日本臨床外科学会誌 $68: 3126-3129$

10. 藤江小百合, 矢上晶子, 鈴木加余子, 他 (2004) : 注腸カテーテルでアナフィラキシーショック を扢こしたラテックスアレルギーの1例。アレルギー $53: 38-42$

11. 山口由衣, 内田敬久, 大砂博之, 他 (2004) : 薬剤アレルギーが疑われたラテックスアレルギー の1例. アレルギー $53: 34-37$ 


\section{A Case of Intraoperative Latex Anaphylaxis during General Anesthesia for Rectal Cancer Resection}

\section{Toshihisa Tamura, Aiichiro Higure, Naoki Nagata, Keiji Hirata, Yoshifumi Nakayama, Kohji Okamoto and Koji Yamaguchi}

Department of Surgery I, School of Medicine, University of Occupational and Environmental Health, Japan. Yahatanishi-ku, Kitakyushu 807-8555, Japan

Abstract : A 72-year-old woman underwent high anterior resection for rectal cancer. Fifteen minutes after the start of the operation, the pressure on the respiratory tract rose, blood pressure and $\mathrm{SpO}_{2}$ dropped, and skin rash, wheezing and ECG disorder appeared. The anesthesiologist suspected latex anaphylaxis and interrupted the operation. The patient was treated immediately for anaphylactic shock, and recovered. Post-operation, she showed positive reaction to latex specific $\mathrm{IgE}$, suggesting that the anaphylaxis was induced by latex allergy. A re-operation was performed under a latex-free environment. No allergic reaction was seen during or after the re-operation.

Key words : latex allergy, anaphylactic shock, general anesthesia.

J UOEH $31(1): 63-69(2009)$ 